\title{
Sacramental Exchange: Eschatological Economy and Consumption Ritual
}

\author{
Kimberly Belcher \\ Department of Theology, University of Notre Dame, Notre Dame, IN 46556, USA; kim.belcher@gmail.com
}

Received: 30 September 2020; Accepted: 26 October 2020; Published: 5 November 2020

\begin{abstract}
Contemporary sacramental theology construes the sacraments as a symbolic gift exchange between God and humanity; God initiates in the ministry of Jesus Christ, and human beings acknowledge and respond to God's gift. The gratuity of that initial gift is ensured not only by reference to God's all-sufficient nature, but also in many cases by excising economic value and economic exchange from the symbolic realm within which the sacramental gift exchange proceeds. This poses an intellectual and a practical problem. Intellectually, economic exchange is fundamentally symbolic and even ritualistic, so that the division between them is difficult to define and maintain. Practically, economic behavior is morally relevant, and the sacraments ought to give some purchase on marketplace behavior. In this essay, anthropological and economic work on "consumption rituals," based on the work of Mary Douglas and Baron Isherwood, is brought to bear on defining the relationship between sacraments and economic exchange and articulating the sociological preconditions for experiencing market exchange as an extension of sacramental gift exchange.
\end{abstract}

Keywords: Chauvet; Douglas; gift exchange; sacramental theology; symbolic order; anthropology; economy; eschatology

\section{Introduction}

Contemporary sacramental theology construes the sacraments as a symbolic gift exchange between God and humanity; God initiates in the ministry of Jesus Christ, and human beings acknowledge and respond to God's gift. Gift exchange has, on the one hand, an appeal as a mundane realm where modern people attempt to maintain a gratuity akin to the "non-value" (Chauvet 1995, p. 45) and, on the other hand, the support of literature, notably Marcel Mauss's The Gift (Mauss 2000). The literature often opposes God's gifts to the fundamentally reductive and depersonalizing forces of economics (e.g., Chauvet 1995; Bieler and Schottroff 2007). The superabundance of sacraments is thus distinguished from purchase exchange.

Excising economic value and economic exchange from the symbolic realm within which the sacramental gift exchange proceeds poses an intellectual and a practical problem, however. Intellectually, economic exchange is fundamentally symbolic and even ritualistic, so that the division between them is difficult to define and maintain. Practically, economic behavior is morally relevant, and the sacraments ought to give some purchase on marketplace behavior. The anthropological economic work of Mary Douglas and Baron Isherwood, Douglas's work on group and grid, and the concept of condensed symbols more precisely define the relationship between sacraments and economic exchange and the sociological preconditions for experiencing market exchange as an extension of sacramental gift exchange.

The Latin tradition of the sacrum or admirabile commercium (sacred or wonderful exchange) and the eschatological character of Christian exchange complements these sociological preconditions. In this liturgical tradition, the relationship between God and humanity is metaphorically read as an exchange: 
having received the humanity of the Word as a gift from Mary, God returns to human beings a share in the divine nature.

There is more continuity than discontinuity between gift and market exchange because both are symbolic ways of structuring human social bonds. By recognizing this fact and its anthropological foundations, Christian sacramental practice might be extended redemptively into the realm of market exchange. Even within a world dominated by market forces which individual Christians do not control, a sacramental approach to the ritual consumption is possible and, indeed, has a moral force. By attending to the practices of a ritualized economy within the ambit of the eschatological revelation, I intend to take seriously Vincent Miller's proposal that the contrast between Christian theology and consumer culture demands a practical, not propositional, response, as well as his thesis that consumer and Christian practice is not irreducibly at odds (Miller 2005).

In the next section of this article, I compare the definition of symbol in Louis-Marie Chauvet's influential work to a phenomenological reading of economic exchange. In Section 3, I introduce the economic principles of consumption rituals and the anthropological concepts of group and grid in order to better understand the sociological differences at stake. In Section 4, Christian eschatology provides a more robust foundation for a distinction between these two types of exchange, as well as a principle of relationship between them. Finally, in Section 5 and the conclusion, I lay out the theological and anthropological implications for a sacramental practice of consumption rituals.

\section{The Symbolic Force of the Economic Order}

In Symbol and Sacrament, Chauvet tries to purify the notion of symbolic exchange, like that which happens in the sacraments, from the economic exchange that is so all-pervasive in our lives. The difference, he says, is a matter of value, or rather, of how value is established:

The logic of the marketplace (under the form of barter or money) is that of value; it belongs to the regime of need which seeks to satisfy itself immediately through the possession of objects. The logic of symbolic exchange is of another order. For what is being exchanged through yams, shells, or spears, as through a rose or a book offered as gifts in our own culture, is more and other than what they are worth on the open market or what they may be useful for. It is more and other than what the objects are in themselves. One is here outside or beyond the regime of usefulness and immediacy. Rather, the principle which rules here is one of super-abundance. The true objects being exchanged are the subjects themselves. By the intermediary of these objects, the subjects weave or reweave alliances, they recognize themselves as full members of the tribe, where they find their identity in showing themselves in their proper place, and in putting others in their "proper place". (Chauvet 1995, p. 106)

I understand Chauvet's purpose here. In his desire to do justice to the sacraments' reshaping of the human person, Chauvet argues that the value of sacramental gift comes from its grounding in a symbolic order rather than in a marketplace exchange. Because the sacramental gift is connected to the symbolic order, and the symbolic order grounds the participants' identities, sacramental participation by Christians is an exchange of subjects with one another that ritually expresses and leads to the ethical verification of love between the brothers and sisters. Replacing the logic of the marketplace, then, with the logic of symbol is supposed to prevent the sacraments' descent into a direct exchange and thereby make room for an alternate logic, that is, the logic of God's incomprehensible and overweening grace.

The symbolic order is a key notion for Chauvet: a whole world of meaning, infused with cosmogonic power, that can nonetheless be evoked by a simple symbolic sound or action. It is marked by the tailored congruence of abundance to one's subjective need. My local parish church manifests a symbolic order, but so too does my local grocery chain.

Waiting in line at the supermarket, suitably masked and distanced six feet from the person in front of me to comply with the state's pandemic regulations, I contemplate the week's 
purchases. I've resisted the branded produce, designed to appeal to my youngest daughter, but I have two half-gallons of ice cream, both on sale this week. I bought milk from the local dairy that also sells at our farmer's market. I bought Doritos and ginger ale. This time of day is always the busiest at the checkout. The cashier offers a ritual greeting as I move to position myself behind the plastic barrier. My pang of worry for her health is a new addition to this familiar ritual. My discount card for the grocery is out, ready to hand over. I know some company uses this card to track my purchases, and probably knows more about my family's preferences and consumption than I do. The credit card I prepare to scan is not morally or symbolically empty either, but because of this fraught visit, when the kids wake up tomorrow, they can have cereal or toast for breakfast. "Did you find everything you were looking for?" the cashier asks me. "Yes," I respond, but I think, as I do every time, I also found a lot of things I wasn't really looking for.

I raise the well-known fact of our ineradicable dependence on the economic system we deplore not to induce hopelessness, but rather to illuminate the fact that it too is a symbolic order; that is, a "system of connections between the different elements and levels of a culture ... forming a coherent whole that allows the social group and individuals to orient themselves in space, find their place in time, and in general ... find their identity in a world that makes 'sense'" (Chauvet 1995, pp. 84-85). This symbolic system both bonds the cultural community and stratifies it into competing subgroups (see Miller 2005, pp. 148-63).

Chauvet's language about symbolic and economic exchange implies a spectrum upon which these dimensions are opposing poles, but cash is a quintessential symbol, one that perfectly exemplifies the cultural embedding and perlocutionary power of the symbolic order. A symbol's " function is to introduce us into an order to which it itself belongs' [since] every symbolic element brings with itself the entire socio-cultural system to which it belongs" (Chauvet 1995, pp. 113-15). ${ }^{1}$ Like Chauvet's word of French when he is alone in China, a printed French franc in 1995 would produce "the recognition of '[France]' present here, the link symbolically renewed with '[French]-ness' ... identify[ing] me as a member of this community, with all that is intrinsically linked to it by way of culture, historical tradition, culinary customs" (Chauvet 1995, p. 119). ${ }^{2}$ However, the American dollar overseas (or the French franc, or, now, the Euro) has a symbolic importance beyond the message it bears serendipitously to the lost traveler. As the effective financial symbol of a stable market and reliable national debt, it also marks an imperial bond of dependence that is beyond my control and frequently invisible to me. Chauvet rightly critiques the way sacramental theology instrumentalizes language, forgetting its symbolic character. The same critique could be applied (as Douglas and Isherwood argue below, Section 3) to the treatments of money that camouflage its symbolism, deepening a global tendency to treat economic value as the one real reality. ${ }^{3}$

This may seem like bad news for Chauvet's theological project, but it is not. Rather, the symbolic reclamation of language and sacrament has the potential to reclaim and redeem economic behavior. Just as we can become aware of the symbolic character of linguistic and gift exchange, economic exchange can also be sacramentalized. This theological work relies on the eschatological character of sacramental symbol as well as benefitting from an update of the anthropological treatment of exchange. Just as Chauvet's work on language nuances our understanding of the sacramentality of ordinary linguistic exchange by renouncing our sense that it is directly representational (Chauvet 1995, pp. 140-52), acknowledging the symbolic character of our economic exchange breaks down the illusion that there is an objective, acultural reality reflected in economic measures like price, income, and GDP. Christians are

\footnotetext{
Quotation from E. Ortigues (1962) Le discours et le symbole (Paris: Aubier-Montaigne), 65. Emphasis in original omitted. Emphasis original. The English translation substitutes "American" and "American-ness" for Chauvet's original, but this muddies the waters here.

3 Not only printed or minted money functions symbolically; any economic standard functions because of a cultural consensus about its value, and so gold, diamonds, or shells are equally symbolic.
} 
then freed to see and manifest the eschatological, sacramental system in their consumption, precisely by paying attention to all its complex nuances and the different symbolic meanings of economic behavior for people in various socio-cultural locations.

The symbolic reclamation of economy has political and moral dimensions: my symbolic resonance with the American dollar and the English language are a sign of my having been made central in a global order; I (by my wallet) participate symbolically in the halls of power, despite the fact that I do not enter there to make decisions. Similarly, on the microeconomic level, my discount card is an effective symbol of my needs and wants, which have been collated and calculated as a "market niche." Because of this behind-the-scenes calculation, and because I am really much like many other members of the United States upper-middle-class, the abundance of the local supermarket meets and exceeds my desires. The discount card and the credit card (with the databases they imply) encapsulate my subjectivity, to the extent that my subjectivity includes (though it is not limited to) what I eat and drink; what I wear; where I go; more than all this, what I am willing to spend. These facts, which might once have related to my role in the cosmic order, are now apparently arbitrary selections I myself can make. Yet these selections are not arbitrary or separable from my religious commitments: "consumer culture is not an expansively plural thing; it appears predictably, conditioned by social norms and in service to social anxiety" (Lofton 2017, p. 284).

I am uneasy about what these facts imply about the global and the cosmic, sacramental order that I partake in. Because the market symbolic order is not recognized as symbolic, it appears to be hermetically sealed. It becomes possible to exist in these two worlds, consoling myself by telling myself that the sacramental order of mutual charity, radical vulnerability, and dependence on God is the real world, but spending most of my money and time in a world structured by physical needs and economic conditions (see Miller 2005 for another critique). Ronald Grimes once memorably wrote of Christian liturgy, "The question is not whether a parishioner remembers the liturgy while pouring tea but whether he or she pours mindfully" (Grimes 2010, p. 36). To pour tea mindfully, though, one must purchase tea mindfully. How do I bear in mind the global economic and ecological ramifications of tea, my guest's favorite flavor, and also my neighbor's restriction to shopping at the Mexican grocery that only has Lipton? In the practice of liturgy, where I take a small place in the future when all things will manifest an end now only realized in Christ, there is an answer (more likely, a range of possible answers, all differently beautiful) to this question.

There are a variety of ways that upper-middle-class conscientious objectors like me can attempt to insulate themselves from the fraught economic world: farmer's markets, farmshares, buying local, Trader Joe's, and fair trade goods facilitate neutral or moral private action within a broken system. This is estimable, and I think such actions should continue for those who can afford them. Many, however, do not have the economic, temporal, or educational privileges to seek and sustain such opt-outs. A sacramental theory of economic consumption cannot privilege the decisions and capacities of upper-middle-class educated professionals. Working class folks, now "essential workers", 4 should not have a second-class sacramental ethic. An eschatological, sacramental subversion of the (apparent) symbolic independence of market exchange, then, has a profound importance to recentering contemporary Christian life.

In the Roman Rite, two of the texts in the Christmas season speak of the Incarnation as an exchange of goods. The Christmas octave antiphon $O$ admirabile commercium: Creator generis humani, animatum corpus sumens, De virgine nasci dignatus est: Et procedens homo sine semine, Largitus est nobis suam deitatem was interpreted by medieval theologians as interpreting the humanity of Christ as a gift given to God by Mary (Herz 1958, pp. 24-49). The antiphon expands on Philippians 2: to the fullness of the Word in the form of God, nothing is lacking but lack. God needs human neediness for the plan of salvation

4 Sixty-nine percent of essential workers do not have a college degree and $45 \%$ of essential workers were persons of color in 2019 (McNicholas and Poydock 2020). For comparison, only 22\% of the total labor force in the U.S. were persons of color in 2018 (U.S. Bureau of Labor Statistics 2019); persons of color are disproportionately employed in "essential" industries. 
(oikonomia); in exchange for human frailty, God returns a share in the divine nature. In the divine economy, God has chosen to make need the ultimate measure of value. It is our need that binds us together into the risen body. In the incarnation, humanity is taken up into the trinitarian exchange of gifts; in the liturgy, culture is taken up into the divine exchange; so, too, economy must be transformed into a participation in the divine exchange.

In the gospels, we do not see an unworldly and economically indifferent Christ; nor do we see a Christ who is concerned to alienate God's grace from economic representation. Our tendency to spiritualize or legalize the economic images of the gospels, in response to our fear of the monetary representation of value, may conceal important truths. Chauvet argues that "ritual dispossession in honor of God is meaningful only if it is 'veri-fied' (made genuine) in an existential dispossession in favor of those in need." (Chauvet 2001, p. 58). It is not need or money that keeps the market exchange from being a privileged locus that reflects the Christian story. Rather, the market exchange departs from Chauvet's symbolic exchange of gifts only insofar as it conceals from me the persons whose labor have made it possible for me to have the object. Inasmuch as it is social, existential dispossession must also be ritualized to be structural. Inasmuch as it is symbolic, it must likewise be economic. Most of all, because it is incarnational and sacramental, it must be grounded on practice for those nearest-not abstract (though gratuitous) gift exchange between isolates, but a high-group community of ritualized, regular help, is the sacramental ideal of economy.

\section{Cash Money: Anthropology, Symbols, and Exchange}

An anthropological approach can provide a broader perspective on the systemic problems that lead Christians to polarize sacramental from economic exchange. Mary Douglas and Baron Isherwood first published in 1979 an intervention into the social sciences that takes human acts of economic consumption as complex, social, communicative practices. According to Douglas and Isherwood, economic analysis is inflected by a presumptive individualism, which influences moral judgements about the economic behavior of the middle class:

[Economists] do recognize two kinds of needs, spiritual and physical, but they accord priority to the physical. They allow it the dignity of a necessity, while they downgrade all the other demands to a class of artificial wants, false, luxurious, even immoral. Luc Boltanski calls this bias, "biological Manicheeism" ... . But the economists who [distinguish biological from spiritual needs] unofficially change the heretical signs, so that the biological becomes a good and the spiritual is unjustified. (Douglas and Isherwood 1996, p. 4)

Even as a sacramental theologian I have found myself unwittingly (and "heretically") according physical needs a higher value than spiritual needs, both in my own life and in my understanding of solidarity. Nonetheless, I remain unable to articulate a point at which buying tea or wine becomes a luxury: by drinking tea (rather than water) have I engaged in a luxury already, or is there a threshold at a particular price point, or according to some other criterion? Anthropological data combats this social-scientific heresy by pointing out that every social group, in any stage of development, prioritizes (though in different ways) the social importance of consumption. At the same time, there is no good, however necessary to survival, that does not speak in social and spiritual terms. Even the very poor willingly prioritize, in some situations, social and spiritual fulfillment over physical subsistence, and for all human persons, both are equally necessary. The underlying structure of society, as well as individual preference, helps determine which relationships are more important than one's physical needs, and which needs, and to what extent. This increased complexification of the anthropological purpose of consumption rituals, as Miller puts it in his use of Bourdieu, "frees us from the totalist pessimism of the commodification of culture. It portrays culture as a much more complex field of action" (Miller 2005, pp. 151-52).

The World of Goods analyzes economic behavior as structured by "consumption rituals." A consumption ritual is a social activity centered around consumption or exchange, which visibly 
makes use of goods. Although such rituals can be motivated by competition, and this leads to widespread disparagement of "display" and "conspicuous consumption," this is not necessarily a mark of consumption rituals or a sign of political ineffectiveness (see Miller 2005, p. 151). Douglas and Isherwood cite an ethnographic study of social drinkers, who timed their drinking tacitly but so precisely that there was less than a quarter-inch difference between the levels of drinkers' glasses in a group at most times. Such ritual behavior promotes social bonding. Standardization of goods may also serve this purpose: if everyone wears the same uniform and is served the same limited-choice foods, group cohesion is improved. In educational environments, the act of complaining about the uniform and the cafeteria food (or, more rarely, complimenting them) itself becomes a ritual that reinforces group bonding. It is not merely consuming together but conversationally evaluating the goods being consumed that provides the value of a consumption ritual: consumption evokes (or mimics) consensus. This process of evaluation is what Douglas and Isherwood term "marking services": there is social value in agreement with the group or in receiving group acknowledgement of your evaluation of a good (Douglas and Isherwood 1996, p. xxii).

Consumption rituals are communicative actions; there is no human consumption, whether of necessities or luxuries, that is not incorporated with the human need for interpersonal love and acceptance. Acknowledging consumption rituals and their marking services, in fact, makes it immediately apparent that no distinction between (physical) necessities and (superfluous, social or emotional) luxuries can be methodologically coherent: food, drink, and shelter, for example, are thick with social communication. Moreover, the assumption that consumption is driven primarily by a desire to maximize pleasure should be corrected with the observation that consumption patterns are generally driven by a desire to be in sync with the consumption of one's social group and to maximize one's influence within that group (Douglas and Isherwood 1996, p. 67). The goal of consumption is not to maximize pleasure but to maximize agreement with and belonging within one's social group: to maximize one's symbolic message (see also Wepener et al. 2019).

The intellectual temptation to be either too optimistic or too cynical about these patterns of group-sustained consumption rituals might be addressed by thinking of consumption rituals as one cultural aspect of maintaining the mishpat of a society. J. P. M. Walsh glosses this term as "having the say": "'Having the say' involves not only our own efforts but also the collaboration of others. It is important to us that others go along with us when we determine that things should be thus and so ... 'Consensus' is what defines a community: a shared vision or feeling that underlies its common life, validating or legitimating what is done, communally and individually" (Walsh 2004, pp. 3-5). Consumption rituals, then, establish who "has the say" and the consensus values of a culture; this is an anthropological fact and morally neutral. Who has a say, what values are legitimated, and how they are enacted in consumption rituals, however, is not morally neutral and demands sustained theological engagement. I do not mean to merely repeat here that economic behavior is morally relevant, but to say that ritual behavior, inescapably intertwined with economic exchange, is itself already morally charged. Ritual behavior, moreover, includes religious but also other consumption activities.

Douglas and Isherwood's treatment of variable patterns of saving and spending depends on Douglas's earlier work on group and grid systems in culture (Douglas 1970). High-group systems have tight bonds between members, but high barriers for entry against the outside world. Members are deeply responsive to one another's needs. Low-group systems have low barriers for entry and exercise less communal control over individual behavior, but include less bonding between members. Grid is an independent variable from group: grid refers to how universal and uncontested a society's categories are. These categories can be expressed with regard to persons by class, caste, gender, or race (for example, with regard to marriageability and vocation), with regard to goods (by solemn rules on what can be eaten or given for occasions), or even with regard to time (for example, one universal calendar that everyone follows).

A low-group, low-grid system like postmodern, pluralistic capitalism in the United States is a system that privileges individual freedom and autonomy over communal norms. There is no universally 
accepted set of standards for behavior and few systems for creating tight and lasting interpersonal bonds within group members. The social upheaval of such a system catalyzes the formation of smaller, high-group subcommunities, which will naturally enhance group bondedness by creating high barriers to entry. The existence of tightly bonded and exclusionary groups, then, is founded on and points to the fundamental social instability of contemporary culture (Berger 2018, pp. 36-37). Chauvet's example bears the marks of a low-group, low-grid culture (Chauvet 1995, p. 119): it is only in a foreign land that contemporary White Westerners feel instantly bonded on the basis of a shared language. Contemporary Black Americans and Hispanics, on the other hand, have cultural expressions of community belonging inherent in shared linguistic symbols; they belong to a higher-group subculture. United States White Catholics might nostalgically remember the rituals associated with being a higher-group subculture in the first two-thirds of the twentieth century, even as we now bear great socio-economic and political privilege (cf. Clark 2020).

Consumption rituals are symbolic activities by which members of a group send messages to one another, and by this means participate in and build up a shared world of meaning. Goods consumed in this system enact the symbolic divisions of social life, from establishing the communal calendar with its festivities to responding to loss with gestures of grief (Douglas and Isherwood 1996, p. 67). By selecting and serving this wine and not that, to this group and not that one, I communicate something about my taste (both a status symbol and an opening for bonding), background, social role, as well as my values. Moreover, values ritually communicated (e.g., generosity, equality, loyalty, hospitality, frugality) are bound up with status and role, since they are culturally and ritually constructed by experiences dependent on class and socioeconomic positionality.

On the one hand, there is a quantitative aspect to these consumption rituals. "The community that involves its members in most social commitments would have the most consumption rituals, and at times of crisis information and support would flow there more freely. Members of another kind of community, less engaged in ritual exchanges, would be more vulnerable to shocks, economic or other" (Douglas and Isherwood 1996, p. xxii). In other words, high-group communities depend on consumption rituals both to maintain their intensive kinship networks and to send suitably nuanced messages about values, social belonging, and expectations. Low-group communities have less extensive kinship groups and those groups are connected by less ritualized behaviors, so they tend to have fewer consumption rituals, including rituals that attend to the needs of individuals in crisis (see also Wepener et al. 2019).

On the other hand, within the purview of a total system, the exchange of goods communicates more complex messages about community values; it is not only how much exchange takes place, but also what and how goods are exchanged that matters. Communities that exchange very specific goods at particular times and places (say, there is only one type of good appropriate as a wedding gift, or there is a particular type of food that is always consumed at this festival), for example, are exercising and reinforcing a high-grid system. If the rhetoric that accompanies the goods is also fixed, this enhances the effect (see Douglas and Isherwood 1996, pp. 46-47). In turn, the expectation that one will receive a wedding gift or a funeral meal exercises and reinforces high-group bonds.

Grid, on the other hand, can be profitably shorthanded with social mobility: in a high-grid system, moving to one social category to another is restricted. There is a power differential between categories ("class"), but it need not be linear or univocal. Each subgroup might exercise power within a particular division of social life, for example, while transition from one subgroup to another is impossible or challenging. Consumption rituals organize the grid of a society in two ways: members might be restricted from the consumption rituals that send messages within social categories they do not belong to, or the goods that are exchanged or consumed in consumption rituals might be marked by one's class.

Social class is constructed and enforced in part by the periodicity or frequency of consumption rituals. High-frequency rituals like daily meals send relatively low-value messages about social value; infrequent consumption rituals such as annual gift exchanges and weddings send louder messages. High-frequency, low-rank consumption rituals recur frequently within the household (food 
acquisition and meal preparation, cleaning, caring for the sick). Community members committed to these high-frequency tasks have less opportunity to attend high-value rituals and therefore exercise a role in constructing the values of culture. Among infrequent events, some consumption rituals (donor dinners with the bishop or political candidate, client appreciation dinners, faculty dinners) are explicitly limited to members of a class with significant socioeconomic and cultural privilege. These, of course, are explicitly opportunities to exercise influence over social policy. Others (weddings, dinner parties, holiday destinations) are implicitly limited to one's own socioeconomic class, reinforcing established modes of influence. Christian anthropology and sacramental theology may espouse an equitable fraternity between Christians, but if a sacramental economy does not relieve low-status persons of their high-frequency tasks (by equitable redistribution or by technological assistance), their voices will not actually be heard.

Economic options exercised by a household or strong-group unit tend to maximize the influence rationally expected by the household over its members' lifetimes. Thus, high-frequency tasks tend to cluster: if one is committed to one high-frequency set of tasks, all other tasks on a similar frequency may be performed by the same person (rotating between tasks), leaving another member of the household free to participate in lower-frequency, higher-status consumption rituals. ${ }^{5}$ Since women usually feed very young children, they tend cross-culturally to be responsible for other high-frequency tasks, making them less available for low-frequency, high-value consumption rituals and contributing to women's lower influence as a group. Technologies, too, are chosen not so much to maximize one's pleasure as to increase the family's leisure to attend higher-status consumption rituals (and thus, the dishwasher and washing machine have greatly increased women's social influence). Sacrificing some subsistence goods or some time for education makes sense if it seems likely to result in more socio-economic influence for the younger generation, but in a highly stratified society, such a choice may be irrational.

Using these theoretical correctives to analyze my grocery store exchange, then, my grocery store experience amplifies the communal dependence (the high group) of my nuclear family unit, because the things in my cart symbolically support the (mundane) consumption rituals for which they are intended, from breakfasts to late night pandemic ice cream. The goods symbolize and manifest our mutual dependence on one another, and purchasing particular goods is a consumption ritual of inclusion for the other members of my household. Even the consumption ritual of putting the groceries away amplifies this symbolic effect: "Oh, you got (or didn't get) my favorite ice cream!" 6 Within this context, the price has no necessary bearing on the gift exchange, just as Chauvet stipulates, because within a high-group, high-grid environment, the family's shared classifications give us an alternate mode of communication by means of goods that is much more direct and nuanced. Moreover, rejecting the price structure is one way of investing goods with quasi-sacral meaning (Belk et al. 1989). I have only a few friends whose needs I would include in this ritual consumption: "hey, I'm going to the store; do you need anything?" These people are within my fictive kinship network.

On the other hand, the cashier and I are not linked by being in a high-group community together. Nor are we linked by a ritualized set of clearly enumerated categories: I have no model of society, for example, that allows me to place her in a universally accepted social location that regulates all our interactions. We are, in the anthropological sense, "isolates" from one another. This specific context

5 A "low-frequency," high-status ritual may in fact occur daily or even more often in the social system (as in the Second Temple context in Section 4), but it typically recurs infrequently for most individuals. People (priests, politicians, etc.) who attend high-status "low-frequency" rituals daily have privileged access to broadcast their values by means of these rituals, and they generally have been released from "high-frequency" tasks like laundry, meal planning and preparation, and cleaning for this high-status social role. Similarly, hiring a housecleaner gives women like me access to high-status consumption rituals like faculty dinners and conferences (but my housecleaner, a woman of color, does not by payment get access to cultural power).

6 This exchange is structured by the contemporary U.S. economic and cultural sphere, especially exemplifying its shift from producer to consumer and commodity to brand models of culture, even as the notion of favorite flavor brings in an orthogonal set of concerns governed by interpersonal knowledge and thought rather than brand loyalty (see e.g., Sherry 1995). 
of the grocery store, then, must impose a grid of categories of its own, and the cashier is held more responsible than I am for maintaining these categories, since she is trained and paid in this context and I come and go. Our symbolic communication, then, is of two sorts: the restricted code ritual language of this cultural setting ${ }^{7}$ and the exchange of US dollars for ownership of goods. The latter is remarkably effective perlocutionary communication (see Douglas and Isherwood 1996, pp. 61-63; Chauvet 1995, pp. 130-33). In a few seconds, a totally symbolic interaction makes me the owner of goods not only in the eyes of the cashier, but of the government. Whereas before I could have been arrested for walking out the door with my ginger ale, now I am only wished a good day.

Money, then, is an effective tool for communication in a low-group, low-grid social environment. In a weak grid system, "the invisible control of fair-comparison rules" is used to reinforce shared values (Douglas and Isherwood 1996, p. 22). In the absence of shared group or well-established grid values, money facilitates communication by producing a near-infinite number of highly effective, universally acknowledged enumerations of value. The best wedding or Christmas gift is one that communicates shared group: not only items that betray personalized knowledge of the receiver, but also ones that manifest shared membership (like a jersey from the shared college or favorite team) are accepted on these grounds. Where group belonging is weak, however, the universal grid allows for closer and more distant relationships to be differentiated by gift giving, symbolically represented by market value or price. The cultural expectation that I should conceal the price of gifts (fading away in the rise of wish lists) does not manufacture a high-group environment or allow for more effective communication, but it does communicate a cultural norm that gifts expressing group membership are more valuable than those expressing shared categories.

In the United States, influence is increasingly held by billionaires. Money's symbolic efficacy allows an illusion that any citizen can obtain such influence by exercising strategies they use for earning and saving. The differences in consumption scale, however, are insurmountable: "The Yurok man did not need to set up barriers restricting admission to the ranks of privilege. Everyone could compete, and the rules of the competition itself, like the market principle, secured further comparative advantages for those who started out well endowed" (Douglas and Isherwood 1996, p. 100). The contemporary American experience is peculiar: the weak grid is ritualized by rules of decorum that pretend to a classless society, but actual socioeconomic mobility is extremely restricted, especially for Native Americans, Blacks, and Hispanics. This fact is camouflaged by the permeation of leisure consumption into classes who might still have precarious subsistence. Leisure consumption sends messages about the consumption preferences and belonging of working- and middle-class people, but these messages are incomparable with those sent by individuals, corporations, and parties with access to mass communication. Political decision-making and mass communications exist within a vastly different consumption scale, and class- and race-based exclusion at this level, often tacit, is self-perpetuating.

Ritualization, then, seems to indicate an equality that does not reflect the reality of the socioeconomic field of the United States. Against this background, professional class methods for opting out of a reductive consumer environment offer an attractively simplistic mode for enforcing my values, even though (I am distressingly aware) they have a very modest impact on the cultural problems of wealth inequity and exploitation of people and nature. Concerns about "virtue signaling" point to the inadequacy of this approach without providing an alternative.

Instead of analytically separating economic exchange from sacramental gift exchange, a symbolic correction of our theological understanding of economics supports the functional verification of the equity of brother and sister within the fictive kinship group of Christianity. It frees me from two competing cosmological conditions, one of which is associated with individual physical need and well-being, and the other of which is the realm of religious desire and action. We need a theology of

7 "Do you have your discount card?" and "Did you find everything you were looking for?" 
sacramental exchange that can facilitate a rehumanization of the economic realm in the micro scale, and a ritual system that allows for the pluralistic reinforcing of shared belonging on the macro scale.

\section{Money Changers: Temple and Body as Condensed Symbols}

Christ's action in the Temple, newly interpreted, might provide the symbolic funds for a sacramental takeover of our economic worldview.

The Passover of the Jews was near, and Jesus went up to Jerusalem. In the temple he found people selling cattle, sheep, and doves, and the money changers seated at their tables. Making a whip of cords, he drove all of them out of the temple, both the sheep and the cattle. He also poured out the coins of the money changers and overturned their tables. He told those who were selling the doves, "Take these things out of here! Stop making my Father's house a marketplace!" ... . The Jews then said to him, "What sign can you show us for doing this?" Jesus answered them, "Destroy this temple, and in three days I will raise it up" ... But he was speaking of the temple of his body. (John 2:13-16, 19, 21)

At first glance, this story supports the notion that (secular) economic and (sacred) worship behavior are to be rigidly separated. Yet this intuition betrays modern discomfort with the reality of first-century Jewish temple worship, which included animal sacrifice and monetary offering. Steven Bryan contests the idea that the Johannine version of this pericope supports a distinction between economic and ritual behavior. "Despite the intuition of modern readers, there is no evidence to suggest that John would have regarded commercial activity in the temple as inherently irreligious or profane. On the contrary, the trade in sacrificial animals and currency exchange served a vital role in the proper conduct of the temple worship" (Bryan 2011, p. 492).

Jesus's action as sign is a prophetic symbolic action pointing to two historical events, each evoked by a scriptural citation. On one hand, the evangelist alludes to the crucifixion: although he cites Psalm 69:9 ("It is zeal for your house that has consumed me"), the lament about the sufferings of an innocent victim who is given vinegar for his thirst cannot but evoke the cross (see Ps. 69:4, 21). The paschal implications are reinforced by the Passover setting and the reference to the resurrection. On the other hand, Jesus's allusion to Zechariah 14:21 ("and there shall no longer be traders in the house of the Lord on that day") points the reader to the destruction of the Temple, the crisis that threatened the very coherence of Israel's existence as a people during the author's lifetime. This event must have seemed very like Zechariah 14: "For I will gather all the nations against Jerusalem to battle, and the city shall be taken and the houses looted and the women raped." The Temple as God's "house" was destroyed in the Jewish-Roman war: in this sense it is Jesus's enemies who have a troubling and ultimately futile zeal for the Temple (Bryan 2011). However, the body of the Son of David is still available as God's house, just as God replaces the "house of cedar" David wishes to make for God with a royal house that God will make for David: "the Lord declares to you that the Lord will make you a house ... I will raise up your offspring after you, who shall come forth from your body, and I will establish his kingdom" (2 Sam 7:11-12). In this latter sense, Jesus's zeal for the house of Israel will indeed be his downfall ("Are you the King of the Jews?" John 18:33).

It is possible, but unlikely, that both Jesus and the evangelist demanded a separation of exchange and Temple antithetical to Jewish ritual worship or that Jesus' critique here regards the behavior of the particular sellers there present. Unlike the framing in Matthew 21:13 ("It is written, 'My house shall be called a house of prayer'; but you are making it a den of robbers"), the scriptural citations here are apocalyptic, not ethical. These factors in John's version suggest the narrative articulates "end-time" questions that arose after the Temple and its worship were destroyed and relates a theology of Christ's body that responds to apocalyptic concerns (Brown 1997). Rather than reflecting the historical situation of Jesus of Nazareth in the Second Temple, the pericope reflects questions about the interface between a post-Temple ritual economy and eschatological worship in the risen body of the Lord. 
Douglas and Isherwood point out, "The stream of consumable goods leaves a sediment that builds up the structure of culture like coral islands. The sediment is the learned set of names and name of sets, operations to be performed upon names, a means of thinking. Enjoyment of physical consumption is only a part of the service yielded by goods; the other part is the enjoyment of sharing names" (Douglas and Isherwood 1996, p. 51). Douglas's earlier work on meal and sacrifice restrictions in the Hebrew Bible (Douglas 1966; Douglas 1972; Douglas 1970, chap. 3) suggests that the flow of animal consumption in Second Temple Judaism articulated a strong-group community for Hellenistic Jews that reinforced a strong boundary between Jewish and Greco-Roman communities despite the incorporation of particular elements of Hellenistic culture. In the Temple exchange of goods, Roman coins that were used in general consumption and exchange were traded for the Tyrian shekel that could alone be used to pay the Temple tax. Likewise, the coins of general circulation were exchanged for the animals that the Law prescribed for sacrifice. Each of these exchanges reinforces the identity of the Temple as a condensed symbol of the distinctive covenant between God and Israel.

The Temple functioned as a condensed symbol for holistic Jewish identity in part because the ritual sacrifices of the Temple (low-frequency, high-status) were symbolically echoed by draining the life (that is, the blood), which belonged to God, from live animals before eating them (high-frequency, low-status) (Douglas 1972, p. 77). The Temple tax, likewise, reinforced communal membership by subjugating individual consumption and savings to the Temple itself. "Corporations, if they have a defined membership ... tend to behave as if they were to live forever. Individuals who belong in such units, and who act on their behalf, are under pressure to take the long view" (Douglas and Isherwood 1996, p. 20). Being an "eternal" institution, the Temple's tax and treasury constrained Hellenistic Jews to prioritize the group's consumption goals over individual or family goals. The function of money changers reinforced the group's boundaries by ritualizing the rejection of Roman coinage, symbolically reinforcing the boundary between daily exchange and Temple exchange and thus reinforcing, much as dietary laws did, the Temple's role as condensed symbol. The Temple treasury also ensures that a tangible symbol of each Jewish male citizen inhabits the Temple complex, and the unit (the shekel) for these symbols is echoed by the measurement for ritual necessities (Exod 30:24).

The destruction of the Temple threatened all this ritual, and thereby the group identity it established. By setting up Christ's body (also destroyed but rebuilt) as the new Temple, the gospel takes for granted and reinforces economic mutuality as one aspect of Christian membership. Like the Temple, Christ's body served as an eternal sign of the group. Giving to or on behalf of the body was worth the sacrifice of individual purchasing power and advantage.

Beyond these sociological factors, however, the gospel narrative describes the event of Christ's arrival as an eschatological interruption of mundane ritual and economic patterns:

By driving out the sellers with their goods, he enacts what he then declares: given the non-negotiable arrival of the time of fulfillment, the temple should already have been the eschatological temple-a house free of traders [Zech 14:21]. That it was not serves as the rationale for the assertion hidden within the following riddle-that through Jesus' death and resurrection a new temple will be raised. (Bryan 2011, p. 494)

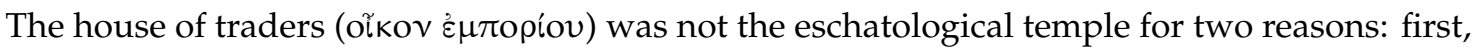
in the eschatological condition, the sacred place overflows and becomes accessible even in the mundane. "The cooking-pots in the house of the Lord shall be as holy as the bowls in front of the altar; and every cooking-pot in Jerusalem and Judah shall be sacred to the Lord of hosts" (Zechariah 14:20). Second, it follows necessarily that there will no longer be a need for boundary keeping between the eschatological Israel and their neighbors. "And the Lord will become king over all the earth; on that day the Lord will be one and his name one" (Zech 14:9). Whereas, as Bryan suggests, the use of Psalm 69 and Zechariah 
14 might signify to readers that those zealous for Herod's Temple were responsible for Christ's death, ${ }^{8}$ the metaphor of consumption also evokes John 6 , in which the new temple is both the bread and the meat of the eschatological community. Zeal for the Temple consumed Jesus and the Jewish community of Jerusalem, but zeal for the new temple leads to consuming him.

In Christian sacramental worship, the eschaton has arrived (in Jesus Christ) but is not yet fulfilled. Christian sacraments are the catalyst by which the risen body of Christ, the heavenly temple, stages a takeover of the "powers of the world." The eschatological charism of the monastic life is revealed like the eschatological arrival described in Zechariah 14, by the radical extension of the sacred into daily bread, made manifest especially in the cooking utensils: "[The cellarer] will regard all utensils and goods of the monastery as sacred vessels of the altar" (Fry 1981, p. 229). Just as temple practice created a condensed symbol with echoes throughout the Second Temple ritual system, consuming the eucharist coalesced for early Christians as a condensed symbol of participation in the eschatological arrival of the risen body of Christ.

Marion Grau discusses the way ransom and redemption function in the New Testament as economic metaphors for salvation in which Jesus, as divine trickster, takes on the role of a slave in order to rescue humanity enslaved by the devil. "The slave, the most unfree member of this society, whose work and life is a commodity, emerges as an agent of liberation. Through a form of divine commerce, the paying of a ransom for the redemption of others, the dominant economy of power is thrown into disarray. Furthermore, Jesus asks those in his company to mimic this economy of voluntary enslavement as a model for redemptive relationality" (Grau 2004, p. 141). This economic metaphor works only in high-group situations, however: "in Hebrew tribal society, an individual had dense connections to the others in his or her community. At least in terms of a narrative device, one person can stand in for others, perform deeds, even live or die for others in the compound" (Grau 2004, p. 144). In a high-grid context, too, the notion of the infinite value of Christ's ransom made sense: "A camouflaged trickster Christ masks his divinity in order to be sold into slavery to free an enslaved humanity. This stealth investment explodes the diabolic bank, breaks the chains, and buys redemption for all" (Grau 2004, p. 159).

If the incarnational principle is evidently eschatological, the manifestation of this principle in sacramental practice has always been complicated. Worldly practices of prioritizing the comfort of the rich over hospitality to the poor already threatened the recognition of the eschatological body in the assembly at Corinth (1 Corinthians 11:21, 29). The practice of eating together made differences in consumption visible, but there was no compensatory practice of prioritizing group needs in consumption, so the supper became the manifestation of social rank.

The complication can be described in sociological terms. The eschatological condition calls for a community that is extremely high-group ("If one member suffers, all suffer together with it; if one member is honoured, all rejoice together with it," 1 Cor 12:26). Unlike a sociological high-group community, though, the fictive kinship group of the eschatological body ought also to be radically unbounded ("the ends of the earth"). Moreover, its radical equality is not low-grid but rather anti-grid: "the last shall be first". These principles can be described in sociological terms, but they can at best be approximated by sociological institutions. The eschatological community, appropriately, transcends and fulfills the anthropological conditions of community. The eschatological condition, then, can only be incipiently performed in the living community of Christians.

There have been various ritual performances of this subversion of the worldly sociological order into the eschatological kingdom. In the early church, fictive kinship was subversively performed in the weekly eucharist. Both economic and religious boundaries had to be negotiated in order to facilitate the eucharistic meal (McGowan 2019). Paul's collections for the church at Jerusalem were,

8 The gospel quotes Zech 12:10 ("when they look on the one whom they have pierced, they shall mourn for him, as one mourns for an only child, and weep bitterly over him, as one weeps over a firstborn") in John 19:37. 
on a larger scale, a corporatization of the consumption economy of the emerging network of churches. The exchange of letters and other intellectual productions could not alone sustain the fragile collective. It is no accident that Justin Martyr's discussion of the Sunday eucharistic meal in his First Apology includes the communal care of the assembly:

Bread and wine and water are brought ... [then] the distribution and participation by everyone in those things over which thanks have been given takes place; and they are sent to those not present through the deacons. And those who have the means and so desire give what they wish, each according to his own choice; and what is collected is deposited with the president. And he provides for both orphans and widows, and those in need through sickness or through other cause, and those who are in prison, and strangers sojourning, and, in a word, he becomes a protector for all those who are in want. (Bradshaw and Johnson 2019, p. 27)

Even correcting for the idealization of Justin's apology, this is a description of a high-group and high-grid economy anchored by the weekly ritual consumption of the meal.

High groups are generally held together sociologically by restrictions on entry. There was thus a tension from the beginning between the universal nature of God's call and the equalizing nature of the brotherly and sisterly love within the community (Gal 3:26-29). Early Christians ritualized this paradox in part by offering an equal share in the good news and baptism to all, but restricting the covenant meal and the communal, need-based economy to those who had received initiation. Likewise, ritualized consumption might be primarily within the local community, where members knew each other personally and could develop strong bonds. These local communities provided a foundation for the extension of fictive kinship to members of other local communities.

Later attempts at negotiating the paradox relied on subverting the logic of hierarchy, by demanding more of those with more authority or security, for instance. The Rule of Benedict, to take one example, not only declared the mundane vessels to be as holy as those of the altar, but also privileged welcoming the stranger, who would become Christ and be brought into the center of the community to pray in the oratory and eat at the common table (RB ch. 34; see Belcher 2020a; Belcher 2020b, ch. 9). This subversive centering of the margins, however, remained ritually powerful precisely because the community's boundaries were strongly enforced-the Rule even ritualizes discouraging potential novices (RB ch. 58). The Rule likewise describes a very high-grid community: the abbot or abbess has complete authority and the rank established by seniority in the community can only be disturbed by his or her express judgment.

Even if the monastic life has had a privileged role in reflection on the eschatological condition, the sacraments have certainly been broadly and lastingly pervasive rituals of consumption that express the eschatological subversion of the natural order. The "wonderful exchange" of the Western theological tradition, like my experience in the grocery store, is founded in my finitude, my experience of need. Because of human dependence, the Father, "lover of humanity," sent the Son into the world. When the Word accepted human nature and with it radical ontological dependence, the hierarchical privilege associated with freedom from need was mortally wounded. Just as phenomenological reflection can unconceal the human worth of those who labor to feed me, the incarnation unconceals the conformity between the Word's ontological dependence on the Father (filiation) and the Christ child's physical need for warmth, nourishment, and touch. Such is incarnational exchange, the sacrum commercium.

\section{Turning the Tables: Unconcealing Exchange}

The Christmas octave antiphon expresses the economic principle of eschatology, in which the Word accepts human nature from the human race (represented by Mary's fiat). Having given the Word his needy humanity, the human race receives in exchange a share in Christ's divinity. Divinity may surprise us, though. Whereas humanity may imagine that divinity is marked by solipsistic superabundance, Christ reveals divine exchange. The Father's fullness of being is not insulation, nor is it a simple unidirectional flow from the location of fullness to the sink of emptiness. 
As Origin, rather, the Father is the origin even of passivity, potential to be filled. In the immanent Trinity, the Father's overflowing fullness is met with the Son's acceptance of a share in the divine nature, while the Spirit, "equal Love who is in them both" (Julian of Norwich 2003, chap. 51), prevents value from being reckoned as self-sufficiency. Chauvet, too, speaks about the counterintuitive revelation of the incarnational exchange: "God is nowhere more divine than in the humanity—the sub-humanity—of the Crucified" (Chauvet 1995, p. 493).

In sacramental exchange, the divine sonship characteristic of the Word is offered to fill out human neediness. Human neediness, however, is not eliminated or traded in for an upgrade in this exchange; rather, it is revealed as a gift desired and valued by God. Just as finitude is drawn into the oikonomia by the incarnation, the hunger and thirst of human creatures becomes the demand that serves as the foundation for the sacramental economy. Ambrose dramatizes this by portraying Song of Songs 5:1 as an exchange between baptized Christians and Christ, in which both receive:

You have come, then, to the altar; you have received the grace of Christ; you have obtained the heavenly sacraments. The Church ... . invokes Christ ... "Let my beloved come into his garden and eat the fruits of His apple trees." ... Gladly did the Lord Jesus receive and with heavenly dignity reply to His Church. He says: "I am come into my garden, I have gathered my myrrh with my aromatical spices, I have eaten my bread with my honey, I have drunk my wine with my milk". (De Sacramentis 4.14-15)

The homily structures the imagined rhetorical exchange with scriptural words, but it also relies on images of exchange, where the goods imagined to be received by Christ are those that have been impressed on the human bodies of the baptizands. Myrrh and spices were in the chrism with which the newly baptized were anointed; bread, wine, and milk and honey were given in communion immediately after baptism (see Johnson 2007, pp. 168-69). It is the human bodies of the initiates, then, that are accepted by Christ as gifts, and presented to the Father, who is after all the origin of all (Belcher 2020b, chs. 5, 6, and 9).

The prayer over the gifts for December 29th extends this principle to the eucharistic liturgy: "Receive our oblation, O Lord, by which is brought about a glorious exchange, that, by offering what you have given, we may merit to receive your very self. Through Christ our Lord" (Catholic Church and United States Conference of Catholic Bishops 2011, p. 178). ${ }^{9}$ This text reveals the offerings of the bread and wine (gifts previously received from God) as the means of salvation. The metaphor of exchange suggests that Christians contribute and that their contribution is necessary. The gift received (Christ himself) is much more valuable than what is offered for it (one always trades up), but at the same time the gifts are elevated by being deemed worthy of exchange. The sacramental exchange honors the gift given and the gift received; it reveals the interdependence of the members in the exchange. During the preparation of the gifts, the mixing of water and wine is also compared to the wondrous exchange of the incarnation: "By the mystery of this water and wine may we come to share in the divinity of Christ who humbled himself to share in our humanity."

In each of the three exchanges modeled in Figure 1, the human perspective is represented by the lower end of the diagram. The upward (anabatic) direction of exchange represents a less valuable good, but at the same time, it can be integrated into the upper good without changing its essential character (e.g., the wine remains wine after being mixed with water). Moreover, by accepting the less valuable good, the divine agent comes to be more perfectly manifest (for example, Christ comes to be manifested in the eucharistic gifts).

9 Suscipe, Domine, munera nostra, quibus exercentur commercia gloriosa, ut, offerentes quae dedisti, teipsum mereamur accipere. 

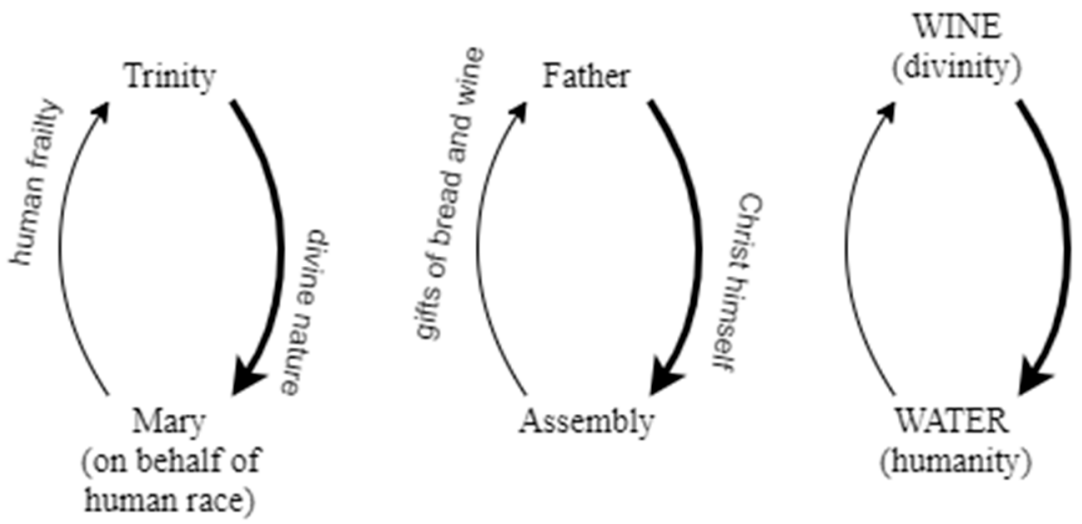

Figure 1. The "wonderful exchange" of incarnation and liturgy: (a) the Incarnation described in the Sacrum commercium antiphon; (b) the liturgical exchange of the Eucharist; (c) the water and wine mixing as a symbol of incarnation and liturgical exchange.

The eschatological and sacramental potential of market exchange, then, is activated when (1) I see myself as receiving more than I give in a market exchange. (2) I receive my goods as the manifestation of a network of life (cosmic and human) that transcends my needs even as it can accommodate my dependence. (3) By the exchange I am drawn more and more into a mutuality of interdependence with those whose needs I mingle with my own. The first two are a matter of sacramental perception, but the last is a matter of empirical fact, a practice (or lack of practice) of group consumption rituals. Consumption rituals must link my mundane eating, drinking, and other goods exchange with my membership in Christ's body, and that membership must manifestly transcend my socioeconomic, racial, and political identity.

To put it in anthropological terms, for the eucharist to be a symbol of the in-breaking of the reign of God, it must be echoed, as a condensed symbol, in the high-frequency, low-status exchanges that are the bread and butter of my consumption.

In a sacramental view, the loaf of bread I purchase at the grocery store becomes the gift that symbolizes (because it truly is) the gifts of the farmers, the harvesters, the bakers, the truck drivers, the market stockers, and the cashiers whose labor have not only made the thing, but brought it to me. Purchasing bread, then, I have entered into a symbolic exchange, if I only know it. To exchange my symbolic currency for physical nourishment has the potential—really, it ought to create a "relationship of alliance, friendship, affection, recognition, gratitude" (107) between myself and these partners. After all, what is my money compared to real nourishment? Like Christ's need on the cross ("I thirst"), my need has created a well of kenotic potential. My cash is thus an ambivalent symbol: it may allow me to conceal my dependence from myself, or alternately it may reveal my dependence on those who feed me; it may name the value I place on their labor.

The cultural forces of concealment may also be described sociologically. First, the myth that money is the real and ultimate arbiter of value conceals the truth of market exchange: one always trades up! The reason I exchange my currency for goods is because the goods are worth more, worth more to me. So my subjectivity, my dependence, is the premise for market exchange, and this premise can only be unconcealed by realizing the symbolic character of all economic exchange. Second, the laborers are concealed by the cultural surround (low-grid, low-group), because there is no ritualized mapping of my social group that requires me to envision their relationship with me. Standardization and packaging camouflage the human hands involved, and my status as "customer," theirs as "customer service" (totally ephemeral roles) prevent either the ritual performance of equality or the ritual performance of difference.

The camouflage extends even to many churches, where the ethnic enclaves of the first half of the twentieth century, with their strongly defined economies of consumption and mutual care, have given way to urban and suburban communities that have widely variant consumption rituals. This is one of the 
cultural costs of performing whiteness in the United States (Grimes 2017a, 2017b). But if the "relationship of filial and brotherly and sisterly alliance" is to be "veri-fied" in a sacramentalized economy of exchange, then the consumption ritual of the eucharist must be echoed in other shared consumption rituals: prioritizing the (quasi-eternal) group's saving over individual saving, exchanging marking services on life cycle events, eating and drinking together for low-frequency, high-status events.

For the eschatological paradox to be realized in these events, though, they must equalize the opportunities for participation, not only between different socioeconomic classes, but between those operating in different economic spheres: those working towards subsistence must sit down at table with those who are affluent. For this to be feasible, consumption rituals must include support for the high-frequency, low-status tasks that are the burden of poverty from an anthropological perspective. The dominance of anonymous, distance philanthropy in the approach of contemporary Christians to economic support poses new (but probably not insuperable) obstacles to experiencing giving as an exchange within a fictive kinship group.

\section{Conclusions}

If we take the divine-sacramental exchange, that is, the economy of salvation, as a starting point to develop principles for sacramental participation in mundane economic exchange, several praxical consequences result. These are characteristics of the consumption rituals of communities that make the eschatological character of the kingdom visible even in their mundane exchange.

1. Need is not only the grounds of sacramental exchange, but also the ultimate currency exchanged in Christian sacramental ritual. Just as the vulnerability of human nature was necessary to the Word made flesh, the vulnerability of human persons is essential to the coherence of the social body. It is consumption, which originates in lack, that grounds the exchange of goods. This exchange creates patterns that constitute human culture: the mutually-agreed value system of culture necessarily includes practiced agreements on the value of material goods. Within a sacramentalized economy, however, need is of the highest value, because it is the quality that has been found acceptable and salvific by the Word (the last shall be first, and the leader of all shall be like a slave). The ability to name and identify need is a qualification of a fictive kinship group. Practices that destigmatize and ritualize names for needs are essential. At the same time, practices that only offer prayer for needs rather than material support may decrease community generosity, camouflaging the eschatological principle (Yasin et al. 2020).

2. The replacement of the Christian ritual meal with a token was early and widespread, but the fictive kinship of Christian ecclesiology cannot be existentially sustained without communal consumption rituals that engage real hunger, thirst, and grief. Ethnic enclave churches have strong outer boundaries and a ritual system surrounding life passage and calendrical rites. These rituals support microrituals communicating belonging: pacing, comparative consumption, and label broadcasting. Ethnic communities worldwide practice these consumption rituals quite naturally, but in an ethnically plural community, they may fade and be replaced only by private or nuclear-familial consumption rites. Community feasts, then, are sociologically essential as a complement to the eucharist.

3. Consumption rituals must tie mundane consumption to the sacred consumption rituals of the church. Connection points may consist of the material goods consumed (e.g., bread and wine), language ritually deployed, eligible participants, or the currency used (e.g., scrip systems). These ritual symbols provide the foundation for recognizing kinship with those within and outside the community.

4. In reinforcing (or making) strong group bonds in an inequitable economic system, it is more essential to provide more choices and access to high-status consumption rituals for non-privileged members than to optimize moral choices of more privileged members. High-frequency tasks (childcare, dishes, packing and bagging) are a predictor of members that need support and choices. Equalizing consumption rituals, then, distribute high-frequency tasks to those whose time is less taken up with such tasks (e.g., to retirees or youth) or to the group as a whole (e.g., babysitting cooperatives). At the same time, they make high-value consumption rituals open to lower-status members of the 
group. As for my own consumption choices, shopping at the Mexican grocery might be an effective act of solidarity as well as a promotion of development and a rejection of de facto segregation. In so doing I use my energy, time, and power of choice to support the choices available to my neighbors whose lives are more consumed with high-frequency tasks and who are outside the privileged sphere of consumption. Such acts must be complemented by opening structural access to marginalized groups and the redistribution of low-status tasks.

5. To proclaim the eschatological completion of the church, high-group communities need consumption rituals that subvert the group's strong boundaries. This is the role of consumption rituals that include and prioritize those outside the usual boundaries of the community. Just as ritual ties (material, language, participants, currency) should unite sacred to mundane consumption rituals, similar ties should unite in-group and out-group consumption (including charity).

6. One corollary emerges in the context of globalization. The "neo-Manichaeism" of economics has contributed to the savior mentality of development. In the worst case, "rich" communities give material goods to materially-poorer communities, expecting nothing (so it seems) in return. This process depletes the economic potential of lower-status communities as well as neglecting their spiritual and social giftedness. Better models of development are emerging, based on the central truth that community and global development must be based on bidirectional exchange, wherein the distinctive gifts of each partner are esteemed (see e.g., Farmer and Gutierrez 2013; Martin 2003; Dawsey 2001). In particular, we can add to the gifts exchanged the ritualized knowledge of how to maintain fictive kinship bonds, which disadvantaged groups so clearly maintain (Wepener et al. 2019; Wepener 2009; Cilliers and Wepener 2007). Liberation-influenced economic development eschatologically expresses the central truth that need is the paradigmatic currency of the kingdom.

The Christian sacramental revelation is not the separation of the eschatological from the worldly, but the subversion of the worldly into the eschatological. To maintain a high-group community, especially in an environment rife with inequity, requires the regular practice of consumption rituals, normally structured by the regular cycles of time, as well as by life-cycle occasional rites and by needs. To be an eschatological unconcealment of exchange, Christian consumption rituals must subversively prioritize group needs and the most vulnerable members above individual autonomy. High-group consumption rituals establish and reinforce the ecclesiological assertion that Christians are brothers and sisters, but consumption rituals that prioritize and serve those outside the community are also necessary to reveal the cosmic extent of God's care. Neither gift exchange nor purchase can be alienated from the sacramental economy: the ordinary values of social life are inscribed by the regular repetition of these consumption rituals.

Funding: This research received no external funding.

Acknowledgments: I would like to thank the anonymous reviewers for Religions for excellent suggestions and encouragement, as well as Matthew Belcher and Nathan P. Chase for reading early drafts of this essay.

Conflicts of Interest: The author declares no conflict of interest.

\section{References}

Belcher, Kimberly Hope. 2020a. Ritual Systems: Prostration, Self, and Community in the Rule of Benedict. Ecclesia Orans 37: 321-56.

Belcher, Kimberly Hope. 2020b. Eucharist and Receptive Ecumenism: From Thanksgiving to Communion. Cambridge: Cambridge University Press.

Belk, Russell W., Melanie Wallendorf, and John F. Sherry. 1989. The Sacred and the Profane in Consumer Behavior: Theodicy on the Odyssey. (How Consumer Behavior Reflects the Secularization of Religion and the Sacralization of the Secular). Journal of Consumer Research 16: 1-38. [CrossRef]

Berger, Teresa. 2018. @worship: Liturgical Practices in Digital Worlds. In Liturgy, Worship, and Society. London: Routledge.

Bieler, Andrea, and Luise Schottroff. 2007. The Eucharist: Bodies, Bread, \& Resurrection. Minneapolis: Fortress Press. 
Bradshaw, Paul, and Maxwell Johnson, eds. 2019. Prayers of the Eucharist: Early and Reformed, 4th ed. Collegeville: Liturgical Press.

Brown, Raymond E. 1997. An Introduction to the New Testament, 1st ed. New Haven: Yale University Press.

Bryan, Steven M. 2011. Consumed by Zeal: John's Use of Psalm 69:9 and the Action in the Temple. Bulletin for Biblical Research 21: 479-94.

Catholic Church, and United States Conference of Catholic Bishops. 2011. The Roman Missal. Collegeville: Liturgical Press.

Chauvet, Louis-Marie. 1995. Symbol and Sacrament: A Sacramental Reinterpretation of Christian Existence. Collegeville: Liturgical Press.

Chauvet, Louis-Marie. 2001. The Sacraments: The Word of God at the Mercy of the Body. Collegeville: Liturgical Press.

Cilliers, Johan, and Cas Wepener. 2007. Ritual and the Generation of Social Capital in Contexts of Poverty: A South African Exploration. International Journal of Practical Theology 11: 39-55. [CrossRef]

Clark, Emily Suzanne. 2020. White Christian Privilege in 2020: A Review Essay. Religions 11: 357. [CrossRef]

Dawsey, James M. 2001. Liberation Theology and Economic Development. American Journal of Economics and Sociology 60: 203-12. [CrossRef]

Douglas, Mary. 1966. Purity and Danger: An Analysis of the Concepts of Pollution and Taboo. London: Routledge.

Douglas, Mary. 1970. Natural Symbols; Explorations in Cosmology, 1st ed. New York: Pantheon Books.

Douglas, Mary. 1972. Deciphering a Meal. Daedalus 101: 61-81.

Douglas, Mary, and Baron C. Isherwood. 1996. The World of Goods: Towards an Anthropology of Consumption: With a New Introduction. London: Routledge.

Farmer, Paul, and Gustavo Gutierrez. 2013. In the Company of the Poor: Conversations with Dr. Paul Farmer and Fr. Gustavo Gutierrez. Edited by Michael Griffin and Jennie Weiss Block Maryknoll. New York: Orbis Books.

Fry, Timothy. 1981. RB 1980: The Rule of St. Benedict in Latin and English with Notes. Collegeville: Liturgical Press. Grau, Marion. 2004. Of Divine Economy: Refinancing Redemption. New York: T \& T Clark International.

Grimes, Ronald L. 2010. Ritual Criticism: Case Studies in Its Practice, Essays on Its Theory. Waterloo: Ritual Studies International.

Grimes, Katie M. 2017a. Breaking the Body of Christ: The Sacraments of Initiation in a Habitat of White Supremacy. Political Theology 18: 22-43. [CrossRef]

Grimes, Katie Walker. 2017b. Christ Divided: Antiblackness as Corporate Vice. Minneapolis: Fortress Press.

Herz, Martin. 1958. Sacrum Commercium: Eine Begriffsgeschichtliche Studie Zur Theologie Der Römischen Liturgiesprache. In Systematische Abteilung 15. Munich: Kommisionsverlag Karl Zink.

Johnson, Maxwell E. 2007. The Rites of Christian Initiation: Their Evolution and Interpretation. In Revised and Expanded. Collegeville: Liturgical Press.

Julian of Norwich. 2003. Showing of Love. Translated by Julia Bolton Holloway. Collegeville: Liturgical Press.

Lofton, Kathryn. 2017. Consuming Religion. Chicago: University of Chicago.

Martin, Edward J. 2003. Liberation Theology, Sustainable Development, and Postmodern Public Administration. Latin American Perspectives 30: 69-91. [CrossRef]

Mauss, Marcel. 2000. The Gift: The Form and Reason for Exchange in Archaic Societies. New York: W. W. Norton \& Company.

McGowan, Andrew. 2019. The Firstfruits of God's Creatures': Bread, Eucharist, and the Ancient Economy. In Full of Your Glory: Liturgy, Cosmos, Creation: Papers from the 5th Yale ISM Liturgy Conference, 18-21 June 2018. Edited by Teresa Berger. Collegeville: Liturgical Press Academic, pp. 69-86.

McNicholas, Celine, and Margaret Poydock. 2020. Who Are Essential Workers?: A Comprehensive Look at Their Wages, Demographics, and Unionization Rates. Economic Policy Institute. Available online: https://www.epi.org/blog/who-are-essential-workers-a-comprehensive-look-at-theirwages-demographics-and-unionization-rates/ (accessed on 26 June 2020).

Miller, Vincent. 2005. Consuming Religion. New York: Continuum.

Ortigues, Edmond. 1962. Le discours et le symbole. Paris: Éditions Aubier Montaigne.

Sherry, John F. 1995. Marketing and Consumer Behavior: Into the Field. In Contemporary Marketing and Consumer Behavior: An Anthropological Sourcebook. Edited by John F. Sherry. Thousand Oaks: SAGE Publications, pp. 1-44. 
U.S. Bureau of Labor Statistics. 2019. Labor Force Characteristics by Race and Ethnicity, 2018: BLS Reports: U.S. Bureau of Labor Statistics. October. Available online: https://www.bls.gov/opub/reports/race-and-ethnicity/ 2018/home.htm (accessed on 26 June 2020).

Walsh, J. P. M. 2004. The Mighty from Their Thrones: Power in Biblical Tradition. Eugene: Wipf and Stock.

Wepener, Cas. 2009. From Fast to Feast: A Ritual-Liturgical Exploration of Reconciliation in South African Cultural Contexts. Liturgia Condenda 19. Leuven: Peeters.

Wepener, Cas, Ignatius Swart, Gerrie Ter Haar, and Marcel Barnard. 2019. Bonding in Worship: A Ritual Lens on Social Capital in African Independent Churches in South Africa. Leuven: Peeters.

Yasin, Kidist Ibrie, Anita Graeser Adams, and David P. King. 2020. How Does Religion Affect Giving to Outgroups and Secular Organizations? A Systematic Literature Review. Religions 11: 405. [CrossRef]

Publisher's Note: MDPI stays neutral with regard to jurisdictional claims in published maps and institutional affiliations.

(C) 2020 by the author. Licensee MDPI, Basel, Switzerland. This article is an open access article distributed under the terms and conditions of the Creative Commons Attribution (CC BY) license (http://creativecommons.org/licenses/by/4.0/). 